\title{
Temperature and Salinity Effects on Bioaccumulation, Gill Structure, and Radiation Dose Estimation in the Milkfish Chanos chanos Exposed to ${ }^{137} \mathrm{Cs}$
}

\author{
W.R. Prihatiningsih ${ }^{1,2}$, H. Suseno ${ }^{2 \star}$, N.P. Zamani ${ }^{1}$ and D. Soedharma ${ }^{1}$ \\ ${ }^{I}$ Department of Marine Science and Technology, Bogor Agricultural University, Bogor, West Java, Indonesia \\ ${ }^{2}$ Center for Radiation Safety Technology and Metrology, National Nuclear Energy Agency \\ Jl. Lebak Bulus Raya No. 49, Jakarta 12070, Indonesia
}

\section{ARTICLE INFO}

\section{Article history:}

Received 2 November 2015

Received in revised form 1 July 2016 Accepted 17 July 2016

\section{Keywords:}

Global warming

Bioaccumulation

Chanos chanos

${ }^{137} \mathrm{Cs}$

Erica tools

\begin{abstract}
A B S T R A C T
The present trend of global warming has led to an increase in seawater temperature and salinity. The effects of increasing salinity and temperature on the accumulation of ${ }^{137} \mathrm{Cs}$ by milkfish Chanos chanos was studied under laboratory conditions to obtain information on Chanos chanos adaptability under environmental changes. The uptake of radioactive cesium by Chanos chanos increased with temperature of seawater. The concentration factors $(\mathrm{CF})$ of ${ }^{137} \mathrm{Cs}$ for temperatures of $25^{\circ} \mathrm{C}, 27^{\circ} \mathrm{C}$, $29^{\circ} \mathrm{C}$, and $31^{\circ} \mathrm{C}$ at steady state period were $5.25,5.91,6.78$, and $9.98 \mathrm{~mL} \mathrm{~g}^{-1}$ for the whole-body of Chanos chanos. The concentration factors at steady state $\left(\mathrm{CF}_{\mathrm{ss}}\right)$ of ${ }^{137} \mathrm{Cs}$ for salinities of $26 \%, 29 \%, 32 \%$, and $35 \%$ were $6.23,9.93,9.24$, and $6.86 \mathrm{~mL} \mathrm{~g}^{-1}$, respectively. After temperature exposure to $31^{\circ} \mathrm{C}$, the fish gills showed hyperplasia of epithelial cells in branchial secondary lamellae, congestion of blood vessels, and hypertrophy of pillar cells. The fish from the treatment group exhibited hemorrhage between the branchial secondary lamellae and an abundance of mucous substance in comparison with control group. This study links radionuclide bioaccumulation data and monitoring data obtained in the field and laboratory experiment with radiation dose determined by ERICA Tools, an approach that will enable better linkages to be made between exposure and dose in Chanos chanos and its marine food web.
\end{abstract}

\section{INTRODUCTION}

Development of nuclear facilities, including nuclear power station in Indonesia, creates a possibility of a release ${ }^{137} \mathrm{Cs}$ within allowable level into aquatic environment [1]. The radionuclide ${ }^{137} \mathrm{Cs}$ is a fission product which may be present in the low-level aqueous radioactive waste discharged from nuclear facilities. Cesium is of considerable environmental concern because of its high mobility in the marine environment and its ability to accumulate in marine organisms. Understanding the

\footnotetext{
* Corresponding author.

E-mail address: henis@batan.go.id

DOI: http://dx.doi.org/10.17146/aij.2016.539
}

biological fate and transport of cesium in aquatic environment is essential for a sound risk assessment of marine ecosystem.

Marine ecosystems are very important in the regulation of the climate, and they are very sensitive to climate change [2]. The predicted impacts of climate change on marine ecosystems can directly and indirectly affect species abundance and distributions, habitat quality, community composition, and changes in population dynamics [2].

The international organization of climate change, the Intergovernmental Panel on Climate Change (IPCC) in its most recent assessment reported that on a global scale, over the period of 
1971 to 2010 , the upper $75 \mathrm{~m}$ of the ocean warmed by $0.11^{\circ} \mathrm{C}$ per decade. The gradual rise in ocean temperature initiates episodes of water evaporation. These two indicators of global warming affect two physical marine parameters, temperature and salinity.

Studies concerning the likely impact of this warming on marine habitats have been limited. Previous study investigated the effects of temperature [3-5] and salinity [6-8] on aquatic organisms. Moreover, climate change was observed to influence fish reproductive and growth hormones and alter gill structure and genes [9-11]. On the other hand, there have been few studies that investigated how temperature or salinity could affect accumulation of contaminants, especially radioactive contaminants, by marine organisms. Labarthe et al. [12] showed that the increase of temperature and $\mathrm{pCO}_{2}$ as an effect of global warming impacts the bioaccumulation of radionuclides and trace elements in the eggs of Sepia officinalis. The study did not comprehensively discuss the effects of temperature on juvenile stage.

The milkfish Chanos chanos is one of the earliest fish species to be domesticated for food. Studies on the accumulation of radioactive substances by juvenile Chanos chanos have been very limited, especially the ones focusing on the effects of temperature and salinity changes as impacts of global warming. Prihatiningsih et al. (2016) observed that the accumulation of ${ }^{137} \mathrm{Cs}$ on Chanos chanos increased when the body weight increased. Unfortunately, this study did not consider the effects of environmental factors such as salinity and temperature changes as impacts of global warming. Additionally, a particular investigation that is missing from the few previous studies of radionuclide bioaccumulation in fish is the connection between exposure, capability of accumulation, and delivered dose. The use of the ERICA Tool as a new technique in dosimetry modeling and dose estimations can now be applied to extending the results of bioaccumulation investigation to estimating the radiation dose received by fish and other biotas exposed to radionuclides $[13,14]$. However, the application of the ERICA Tool to estimate the time variation of dose rates for fish exposed to radionuclides through multiple routes of exposure has not been conducted.

Further research on target organ as an early damage indicator in fish is also still needed. The gills, which participate in many important functions in fish, such as osmoregulation, respiration, and excretion, are particularly sensitive to changes in water quality as they remain in close contact with the external environment [15].
Changes in temperature, salinity, concentration of heavy metals, and acidity, and other changes in the composition of the environment, as well as other physical and chemical alterations of the aquatic medium, influence the fish gill as an sensitive organ. Heavy metal and acid pollution has been reported to induce desquamation to primary lamellar epithelium and epithelium hyperplasia and alter cell structure $[15,16]$. Moreover, changes in temperature and salinity have also been reported to alter the gill structure in tropical reef fishes [4].

Our objective was to investigate the uptake of ${ }^{137} \mathrm{Cs}$ in juvenile Chanos chanos exposed via seawater. Data on ${ }^{137} \mathrm{Cs}$ accumulation and its concentration in seawater and sediment is useful for risk assessment in Jakarta Bay. In addition to modeling, we used ERICA Tool to estimate dose rates and accumulated doses received by marine organisms, including Chanos chanos, to link radionuclide exposure with dose. Moreover, we also investigated how temperature can affect the structure of gills as sensitive organs dealing with thermal changes in the environment.

\section{EXPERIMENTAL METHODS}

\section{Organisms collected}

Chanos chanos (lengths of 3.2 to $5.8 \mathrm{~cm}$ ) were collected from a fish farm in Tanjung Pasir, Jakarta Bay, Indonesia, in March 2015. Afterwards, they were shipped to the Marine Radioecology Laboratory, Center for Technology of Radiation Safety and Metrology in South Jakarta, where they were acclimatized to laboratory conditions. The Chanos chanos were gradually acclimatized to experimental conditions, including temperature $\left(25^{\circ} \mathrm{C}, 27^{\circ} \mathrm{C}, 29^{\circ} \mathrm{C}\right.$, and $\left.31^{\circ} \mathrm{C}\right)$ and salinity $(26 \%$, $29 \%$, 32\%o, and $35 \%$ ) for one month prior to the experiment. During this period, the Chanos chanos were fed daily with LJA-3 commercial pellets.

\section{Radiotracers and counting}

The uptake kinetics of ${ }^{137} \mathrm{Cs}$ was determined by using high specific activity radiotracers purchased from Polatom, Poland $\left({ }^{137} \mathrm{Cs}\right.$ as $\mathrm{CsCl}$, $\mathrm{t}_{1 / 2}=30$ years). The radioactivity of the tracers was measured nondestructively using an $\mathrm{NaI}$ gamma detector (Bicron type 3428) at $661.66 \mathrm{keV}$ connected to a multi-channel analyzer and a computer equipped with Genie-2000 spectra analysis software. Standard sources of known 
activities and appropriate geometries were used to determine the radioactivity by comparison.

${ }^{137} \mathrm{Cs}$ uptake experiments were conducted using six individual animals held in 101 for each temperature and salinity. Animals of similar size were used to minimize the possibility of size-related differences in radioisotope uptake. The nominal activity of the ${ }^{137} \mathrm{Cs}$ radiotracer was $2 \mathrm{kBq} / \mathrm{l}$. The seawater was renewed daily during the first week, then it was changed every second day in order to keep the radioactivities in the seawater at a constant level. The activity of the radiotracers in the seawater was checked daily to calculate the timeintegrated activities of the tracer [17]. The Chanos chanos were counted for 15 minutes.

\section{Kinetics}

The uptake of the radiotracers from water was expressed as a change in the concentration factor (CF). The $\mathrm{CF}$ of ${ }^{137} \mathrm{Cs}$ is defined as the ratio of the activity per unit mass in the fish $\left(\mathrm{Bq} \mathrm{g}^{-1}\right)$ to the activity per unit volume in the water $\left(\mathrm{Bq} \mathrm{mL} \mathrm{m}^{-1}\right)$, which is calculated as the mean before and after the exposure for each time point. The uptake rate was calculated as the slope of the linear regression line between the $\mathrm{CF}$ and the time of exposure multiplied by the concentrations of dissolved Cs. The uptake kinetics was described by using a single-component first-order kinetic model [17]:

$$
C F_{t}=C F_{s S}\left(1-e^{-k \cdot t}\right)
$$

where $\mathrm{CF}_{\mathrm{t}}$ and $\mathrm{CF}_{\mathrm{ss}}$ represent the concentration factor at time $\mathrm{t}$ (in days) and the steady state concentration factor, respectively, and $\mathrm{k}$ is the rate constant $\left(\mathrm{d}^{-1}\right)$.

\section{Gill histology}

Almost similar with ${ }^{137} \mathrm{Cs}$ uptake experiment, the examined fish were divided into two groups (two samples for each group). The control group was left under normal conditions to study the normal structure of gills, while the second group, or the treatment group, was exposed to high temperatures of up to $31^{\circ} \mathrm{C}$ for $24 \mathrm{~h}$ daily for 10 days. The gills of the test fish were excised, keeping the rakers and the filaments intact. Those gills were then rinsed in normal saline, fixed in $10 \%$ formalin for about $24 \mathrm{~h}$ at $4^{\circ} \mathrm{C}$, then dehydrated in an ethyl alcohol series of ascending concentrations, cleared in xylene, infiltrated with paraffin at $56^{\circ} \mathrm{C}$, then embedded in paraffin wax [18]. Thin sections of the selected gill tissues of about $4 \mu \mathrm{m}$ thickness were cut by means of a rotatory microtome, dehydrated, and stained with haematoxylin and eosin (H\&E), and mounted with di-n-butyl phthalate in xylene (DPX). The sections were examined and photomicrographed using an Olympus microscope fitted with photographic attachment. The prepared slides were used to describe the normal histological structure and histological alterations in the gills.

\section{RESULTS AND DISCUSSION}

The uptakes of ${ }^{137} \mathrm{Cs}$ under different temperatures displayed exponential kinetics reaching a steady state (Fig. 1 and Table 1 ). The $\mathrm{CF}$ of ${ }^{137} \mathrm{Cs}$ for temperatures of $25^{\circ} \mathrm{C}, 27^{\circ} \mathrm{C}, 29^{\circ} \mathrm{C}$, and $31^{\circ} \mathrm{C}$ at steady-state conditions were 5.25, 5.91, 6.78, and $9.98 \mathrm{~mL} \mathrm{~g}^{-1}$ in whole-body fish, respectively. For different salinities, the uptakes of ${ }^{137} \mathrm{Cs}$ are shown in Fig. 2 and Table 1 . The $\mathrm{CF}_{\mathrm{ss}}$ of ${ }^{137} \mathrm{Cs}$ for salinities of $26 \%, 29 \%, 32 \%$, and $35 \%$ were $6.23,9.93,9.24$, and $6.86 \mathrm{~mL} \mathrm{~g}^{-1}$, respectively.

Table 1. Chanos chanos concentration factor exposed to ${ }^{137} \mathrm{Cs}$ for different temperatures and salinities

\begin{tabular}{cccc}
\hline $\begin{array}{c}\text { Temperature } \\
\left({ }^{\circ} \mathrm{C}\right)\end{array}$ & $\begin{array}{c}\text { Concentration Factor } \\
\left(\mathrm{mL} \mathrm{g}^{-1}\right)\end{array}$ & $\begin{array}{c}\text { Salinity } \\
(\%)\end{array}$ & $\begin{array}{c}\text { Concentration Factor } \\
\left(\mathrm{mL} \mathrm{g}^{-1}\right)\end{array}$ \\
\hline 25 & $5.25 \pm 0.26$ & 26 & $6.23 \pm 0.31$ \\
27 & $5.91 \pm 0.30$ & 29 & $9.93 \pm 0.50$ \\
29 & $6.78 \pm 0.34$ & 32 & $9.24 \pm 0.46$ \\
31 & $9.98 \pm 0.50$ & 35 & $6.86 \pm 0.34$ \\
\hline
\end{tabular}

The results of the present study demonstrate temperature-enhanced initial uptake rates of ${ }^{137} \mathrm{Cs}$ from water. Increases in accumulation rates at higher temperatures may be partially due to amplified metabolic activity. Animals were observed to be much more active at $31^{\circ} \mathrm{C}$ than at $25^{\circ} \mathrm{C}$ and the increased internal circulation of water through the digestive systems and respiratory may result in enhanced in the amounts of all elements bound to internal body surfaces. In addition, production of metal-binding proteins or external mucus may be greater at elevated temperatures.

Our study indicated that the Cs uptake was considerably affected by ambient salinity, consistent with many previous observations on the effects of salinity on bioaccumulation [19]. The concentration factor of cesium increased with salinity at the salinity range of 26 to $29 \%$ and started decreasing with salinity from 32 to $35 \%$. This study observed that the optimal salinity for bioaccumulation in Chanos chanos was $29 \%$. Various mechanism have been proposed for the underlying salinity effects, 


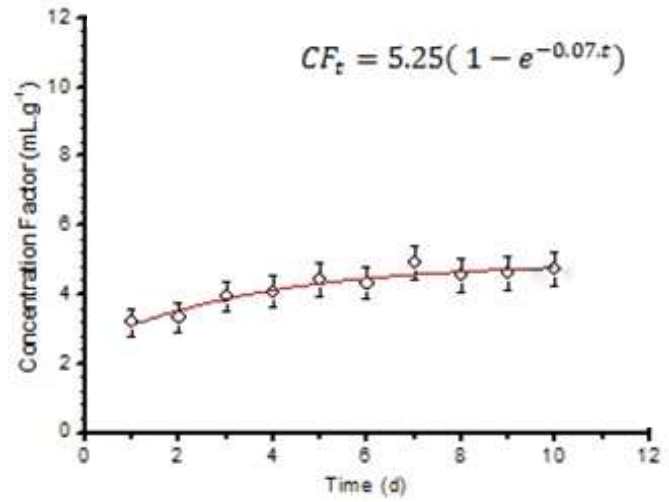

(a)

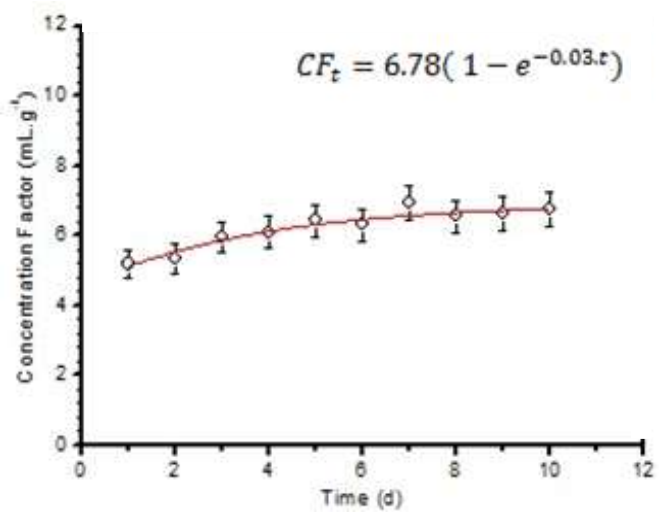

(c)

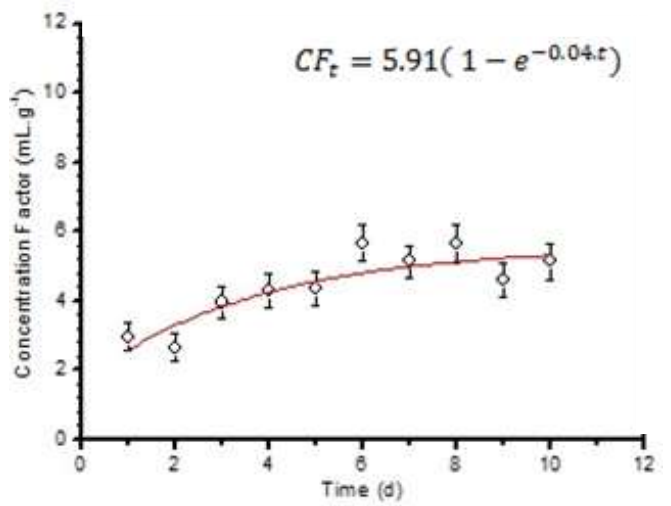

(b)

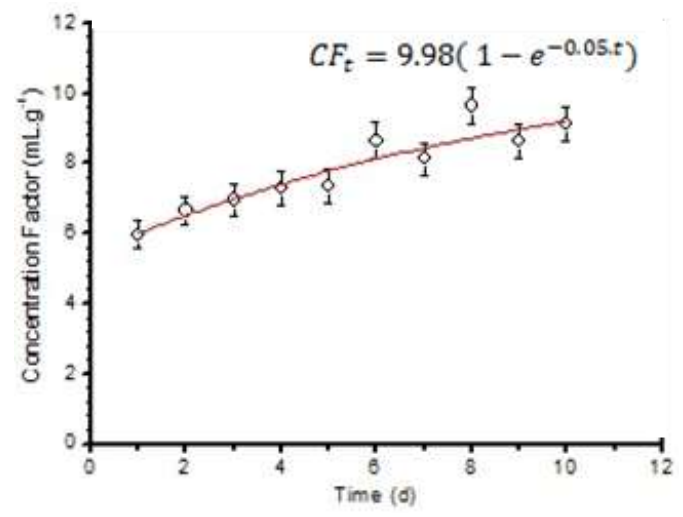

(d)

Fig. 1. Uptake kinetics of ${ }^{137} \mathrm{Cs}$ by Chanos chanos in different seawater temperatures (a. $25^{\circ} \mathrm{C}$, b. $27^{\circ} \mathrm{C}$, c. $29^{\circ} \mathrm{C}$, d. $31^{\circ} \mathrm{C}$ ).

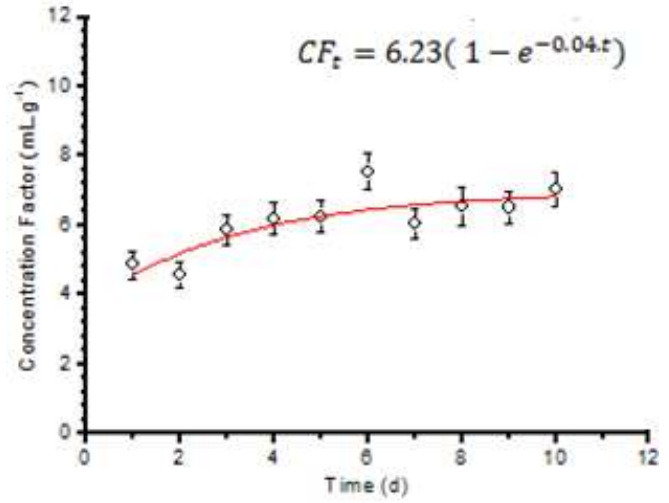

(a)

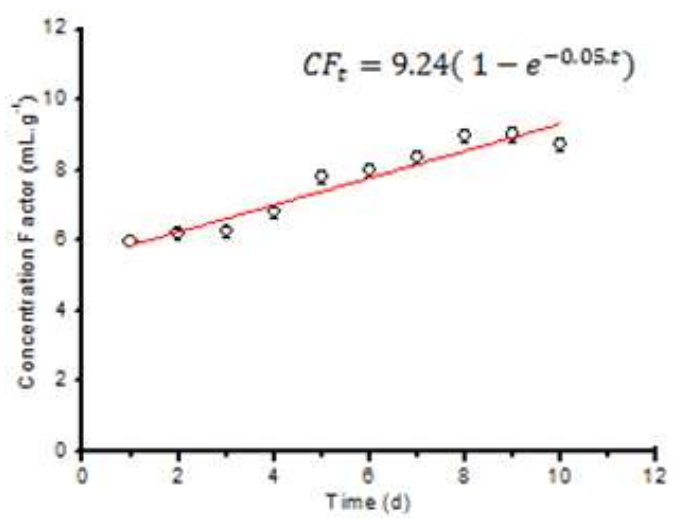

(c)

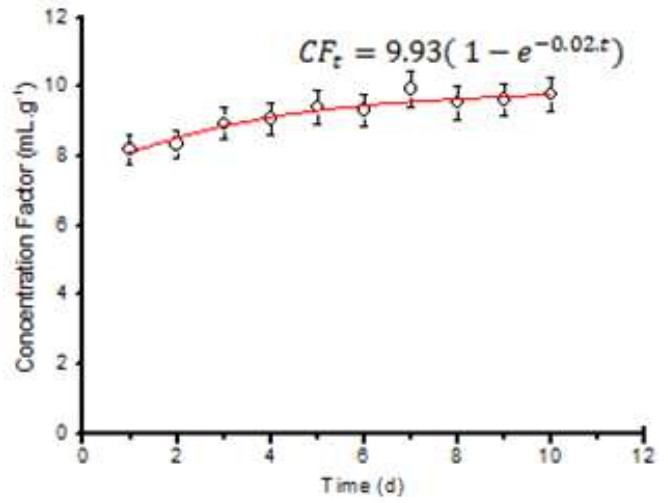

(b)

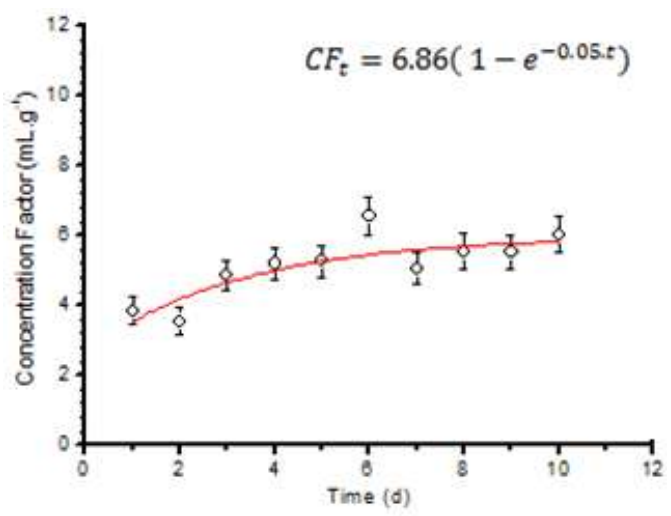

(d)

Fig. 2. Uptake kinetics of ${ }^{137} \mathrm{Cs}$ by Chanos chanos in different seawater salinities (a. 26\%o, b. 29\%o, c. 32\%o and d. 35\%o). 
including the physiological conditions of the Chanos chanos such as respiration rate, or change in cell volume and permeability of tissue. Wang (2000) demonstrated that the variability of cesium uptake at different salinities was primarily due to a change in ambient $\mathrm{K}^{+}$concentration. Further studies are needed to determine the influence of $\mathrm{K}^{+}$related to salinity effect on Chanos chanos bioaccumulation.

The main project of ERICA Integrated Approach is the quantification of risk or risk assement to the environment for a given release of radioactivity. To attain this aim, the data on environmental dosimetry and transfer characteristics of radioisotopes in the environment are combined to provide an estimate of exposure. Furthermore, the ERICA Integrated Approach recommends the use of expected values (or best estimates) of activity concentrations. The assessment chronology in this study uses normal ${ }^{137} \mathrm{Cs}$ activity concentration in seawater and sediment [20]. On other hand, the distribution coefficient $\left(\mathrm{K}_{\mathrm{d}}\right), \mathrm{CF}$, radiation weighting factor, and uncertainty factor in each organism were taken from secondary data which is prepared by ERICA. The screening dose was set at $10 \mu \mathrm{Gy} \cdot \mathrm{h}^{-1}$.

The concentration factor for cesium is a critical value in a risk assessment study of the environmental effect of cesium in coastal and offshore environments. Additional concentration factor data is needed to better describe the distribution of cesium concentration factors in the edible portions of animals used for food. Generic concentration factors are appropriate for use only in a screening-level assessment.

The results of the risk analysis in Chanos chanos and other organisms in marine food web are listed in Table 2. These results indicated that all of the total dose rates for all organisms studied were lower than the screening dose rate $(10 \mathrm{mGy} / \mathrm{h})$. Based on the results from the Tier 2 assessment (Table 2), it is concluded with confidence that there will be no impact on Chanos chanos and other organisms in the food web because all calculated doses listed in Table 2 are lower than the $10 \mu \mathrm{Gy} / \mathrm{h}$ screening level at Tier 2. Given the results shown in Table 2, if ${ }^{137} \mathrm{Cs}$ release actually occurs with activities close to the environmental monitoring data used here, the ERICA Tool would suggest that further investigations are not warranted. A range of decisions will then need to be taken, based on the suggestions given in the generic ICRP exposure situations [13].

Environmental conditions can result in compensatory mechanisms that deal with environmental stressors, as in cellular hyperplasia, and in direct toxic effects of the pollutants leading to necrosis and degeneration [15]. In the present case, it seems that the results are in the form of compensatory mechanisms. All histological lesions observed in the gills of Chanos chanos in this study, are categorized under cellular atrophy, lamellar cell hyperplasia and hypertrophy, hemorrhage and bloody congestion, lamellar damage, and lamellar fusion; these results could be linked with increase in the activities of the test organisms exposed to the changing habitat temperature.

Table 2. ERICA Tool tier-2 assesment for total dose rate

\begin{tabular}{lcccc}
\hline & External & Internal & $\begin{array}{c}\text { Total Dose } \\
\text { rate }\end{array}$ & $\begin{array}{c}\text { Screening } \\
\text { Value }\end{array}$ \\
\cline { 2 - 5 } Organism & $\begin{array}{c}{ }^{137} \mathrm{Cs} \\
\left(\mu \mathrm{Gy} \mathrm{h}^{-1}\right)\end{array}$ & $\begin{array}{c}{ }^{137} \mathrm{Cs} \\
\left(\mu \mathrm{Gy} \mathrm{h}^{-1}\right)\end{array}$ & $\begin{array}{c}{ }^{137} \mathrm{Cs} \\
\left(\mu \mathrm{Gy} \mathrm{h}^{-1}\right)\end{array}$ & $\begin{array}{c}{ }^{137} \mathrm{Cs} \\
\left(\mu \mathrm{Gy} \mathrm{h}^{-1}\right)\end{array}$ \\
\hline Benthic fish & $1.82 \times 10^{-5}$ & $1.74 \times 10^{-5}$ & $1.99 \times 10^{-4}$ & 10 \\
Benthic mollusc & $1.94 \times 10^{-4}$ & $9.15 \times 10^{-6}$ & $2.03 \times 10^{-4}$ & 10 \\
Crustacean & $1.76 \times 10^{-4}$ & $1.16 \times 10^{-5}$ & $1.87 \times 10^{-4}$ & 10 \\
Macroalgae & $2.06 \times 10^{-4}$ & $1.64 \times 10^{-5}$ & $2.16 \times 10^{-4}$ & 10 \\
Pelagic fish & $3.54 \times 10^{-7}$ & $1.84 \times 10^{-5}$ & $1.88 \times 10^{-5}$ & 10 \\
Phytoplankton & $4.92 \times 10^{-7}$ & $6.95 \times 10^{-7}$ & $1.19 \times 10^{-6}$ & 10 \\
Zooplankton & $4.27 \times 10^{-7}$ & $1.90 \times 10^{-5}$ & $1.95 \times 10^{-5}$ & 10 \\
Chanos chanos & $8.24 \times 10^{-8}$ & $3.73 \times 10^{-7}$ & $4.55 \times 10^{-7}$ & 10 \\
\hline
\end{tabular}

After exposure to $31^{\circ} \mathrm{C}$ temperature, the fish gills showed hyperplasia of epithelial cells in branchial secondary lamellae, congestion of blood vessels, hypertrophy of pillar cells (Fig. 4), abundance of mucous substance, and hemorrhage between the branchial secondary lamellae (Fig. 5), in comparison with control group (Fig. 3).

Under high temperatures, cellular hypertrophy and hyperplasia are an important feature. Cells are principally derived from the primary lamellae; the cells then migrate distally, resulting in an accumulation of cells at the leading edge of the secondary lamellae [16,21]. As a result, this could contribute to an increase in the diffusion distance from surrounding water to capillaries and simultaneously increase in the amount of tissue in the secondary lamellae and impair the diffusion of oxygen through the swollen epithelium [16,22]. Moreover, the gills showed bloody congestion. Some changes in blood vessels may also occur when fishes suffer a more severe type of stress. In this condition, damaged pillar cells can result in an increased blood flow inside the lamellae, causing dilation of the marginal channel, bloody congestion, or even aneurysm [21]. The rupture of the gill epithelium could effect heamorrhage; this lesion can be understood as a reflection of the direct action of the thermal agent on the tissue [4]. The mucuspacked cavities observed in the gill filaments of Chanos chanos may be considered as an ion trap to concentrate trace elements from surrounding water and favor cell adhesion between the neighbouring secondary lamellae [22]. 


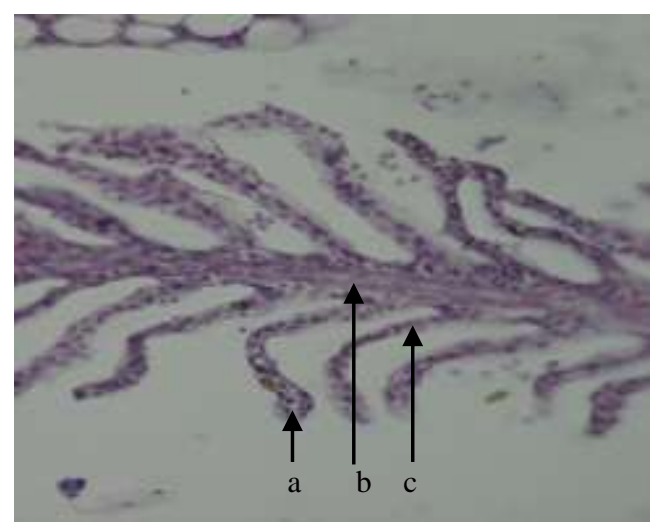

Fig. 3. Gill section from control Chanos chanos showing epithelial cells (a), secondary lamellae (b), and primary lamellae (c). H\&E. $\times 40$.

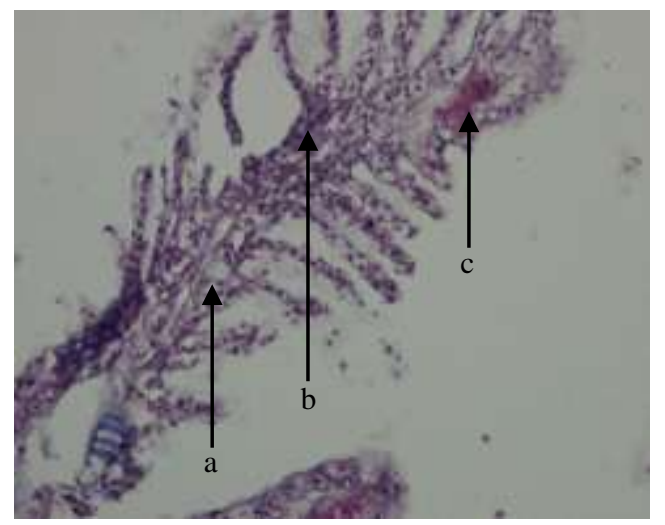

Fig. 4. Gill section of Chanos chanos exposed to $31^{\circ} \mathrm{C}$ temperature showing hyperplasia of the epithelial cells (a), hypertrophy of the pillar cells (b), and blood congestion (d). H\&E. $\times 40$.

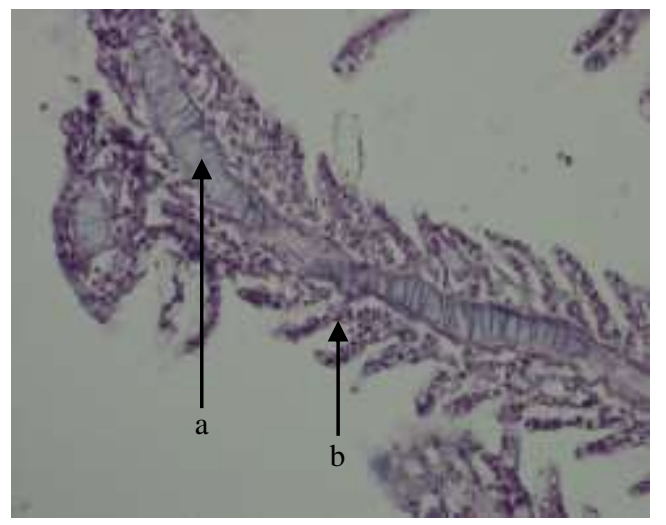

Fig. 5. Gill section of Chanos chanos exposed to $31^{\circ} \mathrm{C}$ temperature showing structure change in primary lamellae (a) and epithelium rupture with hemorrhage (b). H\&E. $\times 40$.

Comprehensive studies that relate the impacts of climate change is greatly needed in the future, as climate changes as mentioned above potentially result in the decrease of ocean $\mathrm{pH}$ due to elevated $\mathrm{CO}_{2}$ concentrations; this could also induce alterations in morphology of gill to keep ion/osmotic and gas exchange balance. This possibility should be considered in future studies.

\section{CONCLUSION}

Environmental factors, including salinity and temperature, affect the metabolism of organisms and their growth and consequently their uptake of cesium. Generally, small increases in salinity and temperature tend to increase the cesium uptake and biological activity. The $\mathrm{CF}_{\mathrm{ss}}$ of ${ }^{137} \mathrm{Cs}$ for temperature $25^{\circ} \mathrm{C}, 27^{\circ} \mathrm{C}, 29^{\circ} \mathrm{C}, 31^{\circ} \mathrm{C}$ were $5.25,5.91,6.78$, and $9.98 \mathrm{~mL} \mathrm{~g}^{-1}$ in the whole body of Chanos chanos. The $\mathrm{CF}_{\mathrm{ss}}$ of ${ }^{137} \mathrm{Cs}$ for salinities of $26 \%$, $29 \%$, $32 \%$, and $35 \%$ were $6.23,9.93,9.24$, and $6.86 \mathrm{~mL} \mathrm{~g}^{-1}$, respectively. Optimum temperature and salinity for bioaccumulation process of ${ }^{137} \mathrm{Cs}$ by Chanos chanos were $31^{\circ} \mathrm{C}$ and $29 \%$. After exposure to $31^{\circ} \mathrm{C}$ temperature, the fish gills showed hyperplasia of epithelial cells in branchial secondary lamellae, congestion of blood vessels, and hypertrophy of pillar cells. The exposed fish exhibited hemorrhage between the branchial secondary lamellae and an abundance of mucous substance in comparison with control group. From ERICA assessment, it was found that the total dose rates for Chanos chanos other organisms in the marine food web and were lower than the screening dose rate $(10 \mathrm{mGy} / \mathrm{h})$, which means that there will be no impact on the Chanos chanos and other organisms in food web because the ${ }^{137} \mathrm{Cs}$ concentration was within the allowable level.

\section{ACKNOWLEDGMENT}

Sponsorship and financial support were given by the Scholarship Programme, Ministry of Research Technology and Higher Education of Indonesia (KEMENRISTEKDIKTI). The authors are thankful for technical assistance from the Marine Radioecology Group, Center for Radiation Safety Technology and Metrology, BATAN, particularly for the marine ecosystem laboratory support.

\section{REFERENCES}

1. W.R. Prihatiningsih and H. Suseno, Mar. Pollut. Bul. In Press, Corrected Proof (2016).

2. O.H. Gudlberg and J.F. Bruno, Science $\mathbf{3 2 8}$ (2010) 1523.

3. R.S. Lugo, C. Mata, A. Oliveros et al., Environ. Toxicol. Pharmacol. 31 (2011) 490.

4. A.J. Bowden, N.M. Gardiner, C.S. Couturier et al., Comp. Biochem. Physiol. 175 (2014) 64. 
5. S.M. Ahmad, F.A. Shah, F.A. Bhat et al., Therm. Biol. 36 (2011) 492.

6. H. Koyama, S. Okamoto, N. Watanabe et al., Comp. Biochem. Physiol. 181 (2015) 59.

7. J.L. Ikerd, K.G. Burnettand and L.E. Burnett, Comp. Biochem, Physiol. 183 (2015) 97.

8. I.S.A. Anni, A. Bianchini, I. Fernanda et al., Aquaculture 455 (2016) 63.

9. F.P. Arantes, H.B. Santos, E. Rizzo et al., Gen. Comp. Endocrinol. 172 (2011) 400.

10. V.D.J. Keller, P. Llyod, J.A. Terry et al., Environ. Pollut. 197 (2015) 262.

11. G. Levy, D. David, G. Degani et al., Comp. Biochem. Physiol. 160 (2011) 381.

12. T.L. Labarthe, S. Martin, F. Oberhansli et al., J. Exp. Mar. Biol. Ecol. 413 (2012) 45.

13. J.E. Brown, B. Alfonso, R. Avila et al., J. Environ. Radioact. 153 (2016) 141.

14. H.C. Reinardy, J.L. Teyssie, R.A. Jeffree et al., Sci. Total Environ. 409 (2011) 3771.
15. A.R. Fonseca, L.F.S. Fernandes, A.F. Fernandes et al., Sci. Total Environ. 530 (2016) 972.

16. M. Minghetti, S. Schnell and M.A. Chadwick et al., Aquat. Toxicol. 154 (2014) 184.

17. M. Metian, M. Warnau, F. Oberhansli et al., J. Exp. Mar. Biol. Ecol. 353 (2007) 58.

18. M. Lai, B. Lu, omprehensive Sampling and Sample Preparation; Tissue Preparation for Microscopy and Histology, Reference Module in Chemistry, Molecular Science and Chemical Engineering (2012) 53.

19. Q.C. Wang, W.G. Shen and Z.W. Ma, Environ. Sci. Technol. 34 (2000) 2711.

20. H. Suseno and W.R. Prihatiningsih, Mar. Pollut. Bull. 88 (2014) 319.

21. N.N. Ortiz, M. Gerdol, V. Stocchi et al., Dev. Comp. Immunol. 47 (2014) 309.

22. W.B. Ameur, Y.E. Megdiche, J.D. Lapuente et al., Chemosphere 135 (2015) 67. 